\title{
In situ growth potential of the subtidal part of green tide forming Ulva spp. stocks
}

\author{
Michel Merceron ${ }^{a}$, Virginie Antoine ${ }^{b}$, Isabelle Aubyc ${ }^{c}$, Philippe Morand ${ }^{d, *}$
}

\begin{abstract}
Institut Français de Recherche pour l'Exploitation de la Mer, Direction de l'Environnement Littoral, BP 70, 29280 Plouzané, France

${ }^{b}$ Institut Français de Recherche pour l'Exploitation de la Mer, Direction de l'Environnement Littoral, avenue du Général de Gaulle, 14520 Port-en-Bessin, France

'Institut Français de Recherche pour l'Exploitation de la Mer, Direction de l'Environnement Littoral, quai du Commandant Silhouette, 33120 Arcachon, France

${ }^{d}$ ECOBIO, Université de Rennes I, Centre National de la Recherche Scientifique, Station Biologique, 35380 Paimpont, France
\end{abstract}

*: Corresponding author : Philippe Morand, email address : philippe.morand@univ-rennes1.fr

\begin{abstract}
:
Ulva spp., the algae most responsible for green tides in Brittany (France), are found on the foreshore and in the most beachward wave area (MBWA) of many bays during green tide phenomena. These algae have recently been seen drifting at greater depths (reaching $-20 \mathrm{~m}$ ). In view of the significant quantities of algae found at these depths, and the less favorable conditions for algal growth than in the intertidal zone, we attempted to determine if they could grow there. For that, during their maximum growth period (from May to July), algae were picked up at three stations located on the foreshore, in the MBWA and in the subtidal (deep) zones of the Bay of Douarnenez, and their nitrogen, carbon and chlorophyll $\mathrm{a}+\mathrm{b}$ contents were determined, and their photosynthetic activity was compared in the laboratory. The intracellular concentrations did not differ much from one station to another, although in the subtidal zone, the irradiance and the nitrogen concentration in the ambient water were much lower than those measured on the foreshore and in the MBWA. Photosynthetic activity characterized by maximum amounts of oxygen produced at different irradiances and by saturating and compensating irradiance levels, was also quite similar at the three stations. The irradiance, temperature and salinity of the subtidal environment, together with the chemical and photosynthetic characteristics of the algae found in that area, are consistent with the hypothesis that they grow there, and that their nitrogen supply comes from nitrogen releases from sediments. Nevertheless, their growth rate is probably less than that of algae in the MBWA.
\end{abstract}

Keywords: Eutrophication; Algal blooms; Ulva sp.; Photosynthesis; Irradiance; Nutrients. 


\section{INTRODUCTION}

Macroalgal blooms (green tides) and phytoplankton blooms are the main evidence of coastal eutrophication, and are widespread throughout the world. Morand and Briand (1996) listed 37 countries including several American states affected by the phenomenon. This number was found to have increased in a recent review (Morand and Merceron, 2004). Schramm and Nienhuis (1996) listed 114 sites in Europe and Asia Minor, where the phenomenon has been observed and described. In France, several regions are affected including the coasts of Brittany (Dion and Le Bozec, 1996), the Arcachon basin (Auby et al., 1994) and the Mediterranean lagoons (De Casabianca, 1996).

Many studies have confirmed the limiting role played by nitrogen in this phenomenon (Sfriso et al., 1988; Fong et al., 1993; Ménesguen and Piriou, 1995; Pedersen, 1995). With only rare exceptions, such as in Western Australia, where intensive farming practices are recent and phosphorus stocks have not yet been created in marine sediments, nitrogen is considered to be the main limiting factor for algal blooms (Morand and Briand, 1996).

Ulva spp. are the most prevalent of the algae found in green tides, which explains why many studies have focussed on their growth (Fortes and Lüning, 1980; Pihl et al., 1996). Their speed of growth has often been linked to the morphology of their thalli (the thin blade facilitates exchanges with the environment) (Littler and Littler, 1980; Rosenberg and Ramus, 1984), to their capacity to store nutrients during pulses (Ramus and Venable, 1987), and to their ability to adapt to varied environmental conditions (Vermaat and Sand-Jensen, 1987; Geertz-Hansen and Sand-Jensen, 1992; Riccardi and Solidoro, 1996).

In Brittany, green tides are mainly due to blooms of two Ulva species, $U$. rotundata Bliding and $U$. armoricana Dion, de Reviers et Coat (Dion et al., 1998), whose morphology and ecological requirements are quite similar. Accumulations on small surface areas and some drifting mats of these algae can be seen on aerial photos taken in the 1950s. Since the 1970s, the phenomenon has increased both in terms of the number of areas affected and the extent of the areas involved, with the biggest increases at the most favorable sites. Two inventories recorded about 50 affected areas (Merceron, 1998, 1999). Sites that favor green tides have several typical characteristics: a gently sloping sandy cove or bay with a wide foreshore exposed at low tide and weak residual currents; water containing little suspended matter; nutrient inputs provided by small local streams loaded with inorganic nitrogen. Classically, algae proliferate in the most beachward wave area (MBWA) during spring and summer when temperature, irradiance and nutrients are optimal for their development. Depending on the local combination of tide, wind and sea conditions, the seaweed can be stranded on the beach or resuspended by incoming tides. The total "intertidal" biomass, i.e. located in the MBWA and foreshore zone of the 15 most affected sites in Brittany has been assessed at 20000 tons of fresh Ulva spp. at the time of the seasonal maximum (Merceron, 1999).

Until recently, this "intertidal" Ulva spp. stock was the only one studied and preventive measures against green tides in Brittany aimed at it only. Yet another stock at a deeper (or subtidal) location, has been documented at several sites in Brittany: in the Bays of Saint-Brieuc, Lannion, Douarnenez and Concarneau (CEVA, 2000; Chaquin, 2000; Merceron and Morand, 2004). Between these two stocks, or rather between the two fractions of the same stock, there is a zone where macroalgae are absent most of the time. It constitutes a strip at the seaward edge of the surf zone, where waves just begin to break. This strip, which is parallel to the shore, is subject to hydrodynamics that prevents drifting, and creates a barrier the algae cannot cross in either direction, except when the sea is completely calm. The deep fraction of Ulva spp. is located beyond the surf zone, usually at depths ranging from 2 to 20 metres. The algae found there are also drifting. They lie lightly on the bottom and are gently resuspended by turbulence. The tonnage of subtidal Ulva spp. was estimated by Merceron and Morand (2004). In the Bays of Douarnenez and Concarneau, the subtidal tonnages were comparable to or higher than those observed in the MBWA and on the foreshore. At Saint-Michel-en-Grève, they were lower than the intertidal tonnages, and at Locquirec they were similar. A survey we conducted in 2000 indicated that this subtidal fraction was often present offshore from the intertidal fractions but also occurred at sites without intertidal algae. 
For green tides we reported in the Bay of Douarnenez, with a mix of $U$. rotundata and $U$. armoricana lying on the seafloor off the surf zone as well as on the foreshore, we showed that temperature, salinity, irradiance and nitrogenous nutrients were suitable for growth of Ulva spp. in a subtidal position (Merceron and Morand, 2004). In view of the significant size of the subtidal fractions, and the fact that they occur despite nevertheless less favorable conditions for algal growth than in the intertidal zone (reduced light due to increased water depth, fewer nutrients due to dilution of stream inputs, lower temperature in spring and summer), the question is whether algae can grow on site, or whether they originate from the intertidal fraction and could return to the more favorable conditions on the foreshore. In order to test if the algae can really grow in the subtidal zone, we measured the nitrogen, carbon and chlorophyll contents of Ulva spp. sampled at three different sites, and estimated their photosynthetic activity in environments reconstructed in the laboratory.

\section{MATERIALS AND METHODS}

\section{Study area}

The Bay of Douarnenez, where seaweed was sampled, is located at the tip of Brittany (Fig. 1). The $8.7 \mathrm{~km}$ wide bay opens toward the west. Its surface area is $252 \mathrm{~km}^{2}$. The water becomes steadily deeper from east to west, reaching a maximum depth of $35 \mathrm{~m}$ at the lowest astronomical tide in the area where the bay opens to the sea.

The catchment area feeding the bay has a total surface area of $298 \mathrm{~km}^{2}$ (Anonymous, 1995), and is mainly used for intensive farming. Fresh water inputs come from several streams located on the southern and eastern edges of the bay. The overall average flow rate is low (approximately $4 \mathrm{~m}^{3} \mathrm{~s}^{-1}$ ). Salinities observed in the bay generally range from 34 to $35 \mathrm{PSU}$. Water surface temperatures usually range from 9 to $18{ }^{\circ} \mathrm{C}$. However, there is greater variation in the surf zone due to the shallowness of the water and the fact that it covers the beach sand daily. The bottoms are generally soft, made up of pale fine sand (medium grain size ranging between 100 and $200 \mu \mathrm{m}$ ), with an increasing proportion of fine particles $(<63 \mu \mathrm{m})$ with depth, but only significant at a depth of $20 \mathrm{~m}$ and over (Bourgoin et al., 1991). The maximum instantaneous currents in the study area are less than $10 \mathrm{~cm} \mathrm{~s}^{-1}$ (Obaton, 1996). Mathematical simulation of currents in the Bay of Douarnenez by SEAMER-CEVA (2001) indicates low residual circulation in the bay, particularly in the eastern part, which promotes eutrophication. The residual current computed was very low, since the residence time of the water in a $500 \mathrm{~m} \times 500 \mathrm{~m}$ cell was over five days in the eastern half of the bay (Obaton, 1996). Intense phytoplankton blooms, some of them toxic, occur frequently (Birrien 1987). The Bay of Douarnenez is the most frequently affected site amongst those monitored by France's toxic phytoplankton monitoring network since 1983.

The bay is also affected by large and recurrent green tides, especially at the beaches fringing the bay between the Aber headland to the north and the town of Douarnenez to the south. Occasional biomass counts were made between 1996 and 1998. The intertidal biomasses present were between 2,173 and $3,385 \mathrm{t}$ of fresh spin-dried seaweed. The total biomass of the subtidal fraction was about the same, whereas, per surface area unit, it varied considerably from almost nil to $1.5 \mathrm{~kg}$ of fresh spindried weight per $\mathrm{m}^{2}$ (Merceron and Morand, 2004). The seabed can be totally overlaid by seaweed, particularly where algae accumulate in shallow depressions.

Algae and water samples were taken and in situ measurements made at the three stations in the southeastern part of the bay, on Le Ry beach and in the immediate offshore area, the first on the foreshore (station A), the second in the MBWA (station B), and the third in a subtidal location (station C) (Fig. 1). The bottom was sandy at all three stations. Station A was located at the mid-tide level and its area was big enough to include variations in the locations of stranded seaweed. Station B covered the western part of Le Ry beach, where algae were present in the MBWA. Station C was located one $\mathrm{km}$ offshore from station $\mathrm{B}$, in an area where subtidal Ulva spp. beds are frequently observed. 


\section{Sampling}

\section{Seaweeds}

Samples were taken seven times at each station in the morning from mid-May to mid-July, which is the period when Ulva spp. growth is thought to be maximal. By sampling weekly, we aimed to study the growth period as precisely as possible.

Samples were taken at stations A and B the same day during low tide, whereas at station C samples were taken two days earlier or later. This interval made it possible to measure the photosynthetic activity on the day following collection of the seaweed after an identical storage period and under controlled conditions. The time-lag was inverted randomly to avoid any possible bias due to a constant order. At station $B$, water depth at the time of sampling ranged from $0.5 \mathrm{~m}$ to $0.7 \mathrm{~m}$; at station $\mathrm{C}$, it ranged from $8 \mathrm{~m}$ to $11 \mathrm{~m}$.

At least five large thalli, in apparently good condition, were randomly sampled at each site. The frequent moving of algae by currents and waves was assumed to prevent any distribution bias. At stations $A$ and $B$, algae were gathered by hand. At station $C$, a small, purpose-built trawl was used. It had a metal frame of $1.00 \mathrm{~m} \times 0.36 \mathrm{~m}$ in contact with the seabed, fitted with floaters at the top to maintain it in a vertical position and with chains at the bottom. A net with a $6 \mathrm{~mm} \times 6 \mathrm{~mm}$ mesh was attached to it. Ulva spp. thalli were collected by slowly towing this little trawl for a few minutes. Thalli from each site were brought back separately in coolers filled with water from the corresponding site, except those from station A for which water from station B was used.

\section{Water}

A water sample was taken at each sampling time and at each of the three stations: at station A by digging a very shallow depression in the sand filled by the surrounding surface water film, at station $B$ by filling a clean bucket in the waves, and at station $C$ by sampling at $0.3-0.5 \mathrm{~m}$ above the seabed with a horizontal Niskin bottle.

The water fraction intended for nitrate (+nitrite) and ammonium determination was filtered through an $85 \mu \mathrm{m}$ porosity membrane and stored in polyethylene flasks, which were immediately placed in a refrigerated cooler. This large mesh size is needed by the $N$ analysis procedure of Aminot (1995), which requires a shorter filtering time at sea. Water was immediately cooled and quickly frozen (within $8 \mathrm{~h}$ ) and special care was taken to avoid the $\mathrm{N}$ water content being altered by plankton growth, excretion or decay or by other means before analysis (see section 4/).

The water fraction to be used to measure photosynthetic activity was brought back to the laboratory in a non-refrigerated cooler with the Ulva spp. from the corresponding station, except for station $A$ for which station B water was used. After being filtered through a $0.45 \mu \mathrm{m}$ porosity membrane, this water was used both to wash the algae before measuring their photosynthetic activity and as the natural milieu of the algae in the apparatus used.

\section{In situ measurements}

\section{Temperature and salinity}

At station $A$, the temperature was measured using a mercury thermometer placed under the layer of stranded algae, whose thickness varied from 1 to $3 \mathrm{~cm}$. The salinity of the water bathing the seaweed was measured using an ATAGO S/Mill refractometer with a salinity measurement range of 0-100. At stations B and C these two parameters were measured using an electrical probe (Kent-EIL 5005).

\section{Irradiance}

Photosynthetically active radiation (PAR: $400-700 \mathrm{~nm}$ ) was measured using two quantum sensors (LICOR). At station A (measurement in the air), we used a horizontally positioned cosine collector (LI190) that measures downwelling irradiance. At stations $B$ and $C$ (measurement in the water), we used a $4 \pi$ collector (LI-193) that measures scalar irradiance. As a matter of fact, seaweeds stranded in station A were generally accumulated in several layers. Thus, only the downwelling light was available for algae, and completely only for the top layer. Conversely, in stations B and C, seaweeds were suspended in the water column or gently lying on the bottom, and using a $4 \pi$ collector was suitable because of light diffusion by suspended matter and reflection by the pale sandy bottom. 
At station B, the measurement was taken at mid depth of the water column. At station C, the irradiance measurement was taken at one meter intervals in the vertical water column so as to compute the average attenuation coefficient. All measurements were taken in the morning, sometimes quite early, when solar radiation was still fairly weak but the sea is generally calmer in the morning before the midday sea breezes start.

\section{Nitrogenous nutrients in water}

Nitrate plus nitrite concentration in water was determined colorimetrically using a Technicon AutoAnalyser II following the method of Tréguer and Le Corre (1974). Ammonium was analysed by fluorimetry with the same apparatus following the method of Kérouel and Aminot (1997). Special care was taken (i.e. very rapid thawing, and analysis within the hour) to avoid $\mathrm{NH}_{4}{ }^{+}$being released from plankton through bacterial activity (Aminot, 1995). The analysis precision was 0.1 and $0.01 \mu \mathrm{mol}^{-1}$ for nitrate and ammonium respectively. The results given by this analysis method have been checked with comparitive tests and have been systematically confirmed.

The concentrations of dissolved inorganic nitrogen (DIN) included N-NO${ }_{3}^{-}, \mathrm{N}-\mathrm{NO}_{2}{ }^{-}$and $\mathrm{N}^{-} \mathrm{NH}_{4}{ }^{+}$, but nitrite-nitrogen was not determined and separated from nitrate-nitrogen since, in comparison with other forms of nitrogen, it is usually very low in the marine coastal environment.

\section{Analyses of Ulva spp. thalli}

The thalli were rinsed in the laboratory. Two pieces of about $10 \mathrm{~cm}^{2}$ were cut out from each of the five thalli collected to measure $C, N$ and chlorophyll $a$ and $b$ contents, and one piece of $4 \mathrm{~cm}^{2}$ to measure photosynthetic activity. The two $10 \mathrm{~cm}^{2}$ pieces were frozen for the analyses.

Carbon, nitrogen and chlorophylls $\mathrm{a}$ and $\mathrm{b}$ in algae

One frozen piece was freeze-dried and ground to a powder. Its carbon and nitrogen contents were determined using a CHN analyser (LECO, model 800). The other frozen piece was used to extract the chlorophylls using acetone after grinding in the dark, and chlorophyll absorption was measured at 750 , 664 and $647 \mathrm{~nm}$ using a spectrophotometer (UV-240-1 PC from Shimadzu). Chlorophyll a and b contents were calculated according to the equations of Jeffrey and Humphrey (1975).

\section{Photosynthetic activity}

On returning to the laboratory, the $4 \mathrm{~cm}^{2}$ piece was put in a pillbox containing water sampled on site. The pillbox was placed in a thermostatically controlled basin at $15{ }^{\circ} \mathrm{C}$ for approximately $18 \mathrm{~h}$.

Photosynthetic activity was measured using the oxygen production of a known quantity of Ulva spp. thallus incubated in the light. A Plant Efficiency Analyser (Hansatech) specially dedicated was used. All the necessary components were bunded inside. The thallus fragment was put into a closed oxygen electrode chamber with an adjustable light source (DW3). Each Ulva spp. fragment was placed in the unit vertically, held between two fine white plastic grids to keep it perpendicular to the unidirectional light beam. The light was red monochromatic $(\lambda=650 \pm 25 \mathrm{~nm})$, emitted from a diode (LH36 type LED) whose intensity was adjustable. The DW3 reaction chamber (holding $18.5 \mathrm{ml}$ ), made of black acetal plastic, was filled with water from the corresponding station, filtered to $0.45 \mu \mathrm{m}$ and temperature controlled at $15^{\circ} \mathrm{C}$. A magnetic stirrer and a polarographic oxygen probe were placed at its base. To calibrate the oxygen measurements, zero was obtained by bubbling nitrogen in the chamber before it was closed to take measurements.

Each measurement was begun by 10 min of adaptation to dark. Changes of the dissolved oxygen during the last $500 \mathrm{~s}$ of this period were recorded (i.e. for a little over $8 \mathrm{~min}$ ), and this was used to determine the respiration rate of the sample. Then increasing irradiance levels were applied $(10,30$, $60,100,150,300,500$ and $1000 \mu \mathrm{mol}$ of photons $\left.\mathrm{m}^{-2} \mathrm{~s}^{-1}\right)$, in successive five-minute sequences. For each irradiance level, the dissolved oxygen concentration in the tank was recorded every second 
during the last $200 \mathrm{~s}$ of the sequence (i.e. for a little over $3 \mathrm{~min}$ ). The variation in the concentration of dissolved oxygen in the measurement unit was recorded along with the irradiance applied. Each Ulva spp. thallus sample was then dried in an autoclave at $60^{\circ} \mathrm{C}$ for $24 \mathrm{~h}$ before weighing.

The net oxygen production value $(P)$ is the difference between the gross rate of photosynthesis and the dark respiration $(\mathrm{R})$. It is a function of the irradiance applied (I). Different equations have been proposed to represent it. We used the TableCurve software to see which of those we tested best corresponded to the series of pairs of values obtained (irradiance applied and oxygen production or consumption). Finally, we calculated photosynthesis indexes $P_{\max } P, I_{k}$ and $I_{c}$ using the equation of Webb et al. (1974):

$P+R=P_{\max }\left[1-\exp \left(-1 / I_{k}\right)\right]$

where $\mathrm{P}_{\max }$, photosynthesis maximum production, is $\mathrm{O}_{2}$-based net photosynthetic activity $\left(\mu \mathrm{mol} \mathrm{O} \mathrm{h}^{-1} \mathrm{~g}^{-1}\right.$ dry weight); $I_{\mathrm{k}}$, saturating irradiance for $\mathrm{P}_{\max }\left(\mu \mathrm{mol}\right.$ photons $\left.\mathrm{m}^{-2} \mathrm{~s}^{-1}\right)$. $\mathrm{I}_{\mathrm{c}}$, compensating irradiance, i.e. irradiance when oxygen production by photosynthesis equilibrates respiration $(\mu \mathrm{mol}$ photons $\mathrm{m}^{-2} \mathrm{~s}^{-1}$ ), is given by the value of $I$ at the point where the curve intersects the abscissa axis.

\section{Statistical data processing}

At each sampling site and date and for the six parameters of Ulva spp. tissue (nitrogen, carbon and chlorophyll $(\mathrm{a}+\mathrm{b})$ contents, $\mathrm{P}_{\max }, \mathrm{I}_{\mathrm{k}}$ and $\mathrm{I}_{\mathrm{c}}$ ) mean and standard deviation were obtained from values of the five individuals sampled.

For each station, the correlation coefficients between the six parameters were calculated. The homogeneity of the standard deviations was tested with the MINITAB software. This condition being fulfilled for $\mathrm{N}, \mathrm{C}$ and $\mathrm{P}_{\max }$, two-way analyses of variance (ANOVA) were then used.

In addition, the similarity between the mean of each of the above-mentioned seaweed parameters at the three stations A, B and C was tested by an ANOVA. For this analysis, the six groups of samples taken in June and July were pooled.

\section{RESULTS}

\section{Physical and chemical characteristics of the study areas}

Table 1 shows temperature, salinity, irradiance, and the concentrations of nitrate + nitrite, ammonium and DIN in the sampling areas.

Temperature varied much more at station $A$ than at the other two stations. This was due to the low thermal inertia of the layer of stranded seaweed and its sensitivity to solar radiation, which raises the temperature, and evaporation, which lowers it. Salinity at station A was also much more variable than at stations $\mathrm{B}$ and $\mathrm{C}$. The nearby stream flowing onto the beach reduced the salinity, which once even reached a nil value, while evaporation at the surface of the sand was the cause of salinity often exceeding 35 PSU.

Overall, irradiance decreased sharply from station A towards station C. At the three stations light variation can be explained by the fluctuations in solar radiation due to the date, the time of day and the cloud cover. In the surf and subtidal zones, possible other factors were the state of the sea surface, water turbidity and depth. At the three stations, the irradiance was lower at the last visit (measurement made early in the morning on July 12 ; very cloudy weather on July 10). At station C, it was lower on July 3 because of cloudy weather. 
At station B, DIN tended to decrease progressively as the season progressed. The same was true at station A, except for June 21, when salinity was also nil, showing that DIN was measured directly in the stream coming from land. At station $\mathrm{C}$, the trend was also to a general decrease over time but no significant conclusion could be drawn. The ammonium values seemed to vary less over the study period and their proportion in DIN rose to reach $90 \%$ by the end of the study.

There was a decreasing gradient of DIN from station A towards station $\mathrm{C}$ that reflected the dilution of the fresh water nitrogen inputs by sea water. Although concentrations at station $C$ were much lower than at stations $A$ and $B$, they remained appreciable (between 3.6 and $8.3 \mu \mathrm{mol}^{-1}$ ), except on June 28 and July 3 (between 1.5 and $2.0 \mu \mathrm{mol} \mathrm{I}^{-1}$ ).

\section{Nitrogen and carbon contents in algae}

The nitrogen and carbon contents in Ulva spp. tissues tended to increase at station B until early June, whereas they were mostly stable at stations A and C (Fig. 2). In early June, the mean nitrogen values at the three stations ranged between 1.8 and $3.3 \%$ of the dry weight (DW) and carbon values ranged between 14 and 28\%. Nitrogen and carbon contents decreased at stations B and C from early June until the end of the measurements in mid-July, while at station $A$ they remained almost at the same level, although they were lower than at the beginning of June. At each of the three stations, nitrogen and carbon contents of tissues were significantly correlated (Table 2). However, whereas ANOVA revealed no significant differences in nitrogen $(p=0.057)$ at the three stations, there were significant differences in carbon $(p<0.001)$.

\section{Chlorophyll and photosynthetic activity}

The chlorophyll $a+b$ content of the thalli tended to drop from late May to late June at the three stations and then to become stable (Fig. 2). The chlorophyll content was generally higher at the subtidal station $\left(2.79 \mathrm{mg} \mathrm{g}^{-1} \mathrm{DW} \pm 1.24 \mathrm{SD}\right.$ at station $\left.\mathrm{C}\right)$ than at the other two stations $(2.36 \pm 1.39$ at station $B$ and $2.01 \pm 0.80$ at station A) (Fig. 2). The decreasing gradient of chlorophyll content from station $C$ towards stations $B$ and $A$ was in the opposite direction from the irradiance gradient. In addition, at each of the three stations, this parameter followed the same pattern as the nitrogen and the carbon content of thalli (Table 2).

Changes in each of these parameters over time were similar (Fig. 3): $P_{\max }$ decreased over the whole period, whereas $I_{k}$ and $I_{c}$ increased, except for the final observation at stations $A$ and $B$, and the last two observations at station $C$ (Fig. 2). This reversal in trends for $I_{k}$ and $I_{c}$ was concommitant with lower irradiance (Table 1) which was observed earlier at station $C$ than at stations A and B. Indeed, the correlation between the irradiance and $I_{k}$ was statistically significant (Fig. 4).

The $P_{\max }$ of the thalli collected at stations $A, B$ and $C$ was statistically different (ANOVA : $p<0.001$ ), with an average of $762.8 \mu \mathrm{mol} \mathrm{O} \mathrm{h}^{-1} \mathrm{~g}^{-1} \mathrm{DW} \pm 151$ (SD) at station $\mathrm{A}, 643.8 \pm 162$ at station $\mathrm{B}$ and $593.1 \pm 159$ at station $\mathrm{C}$. At all three stations, the $\mathrm{P}_{\max }$ values tended to decrease over the study period (station average: $870.3 \mu \mathrm{mol} \mathrm{O} \mathrm{h}^{-1} \mathrm{~g}^{-1} \mathrm{DW} \pm 144(\mathrm{SD})$ in May and $474.3 \pm 98.0$ in mid-July). This decrease was significantly linked to that of nitrogen content (Fig. 5).

Comparison of $I_{C}$ and $I_{k}$ with irradiance observed at stations $B$ and $C$ shows that irradiance was mostly above $I_{k}$ at station $B$, and mostly between $I_{c}$ and $I_{k}$ at station $C$ (Fig. 6). 


\section{DISCUSSION}

The present study, performed with irradiation ranges including those observed in situ, shows that Ulva spp. thalli can grow in their subtidal habitat, as our previous in situ study led us to assume (Merceron and Morand, 2004).

Firstly, the bottom irradiance measured at station $\mathrm{C}$ ranged from 12 to $100 \mu \mathrm{mol} \mathrm{m} \mathrm{m}^{-2} \mathrm{~s}^{-1}$. This maximum value, much higher than the others, corresponded to a combination of very sunny weather, a calm and fairly transparent sea and a depth of only $8 \mathrm{~m}$ on June 28 . Several authors working with various Ulva species have observed thallus growth at irradiances within this range or even lower, the irradiance threshold allowing growth being about $2 \mu \mathrm{mol} \mathrm{m} \mathrm{m}^{-2} \mathrm{~s}^{-1}$ (Table 3). This threshold is approximately as high as $I_{c}$ values we found for station $C$, while irradiance was higher. The chlorophyll $a+$ chlorophyll $b$ content of the thalli tended to drop from late May to mid-July at all three stations. Ulva spp.'s very great adaptability to low or very low irradiance is well known (Table 3). The Ulva spp. thalli in the Bay of Douarnenez thus followed a classic pattern by adapting their chlorophyll content to irradiance variations linked to the location and the time of year. Moreover, the $P_{\max }$ values recorded in the present study, even at the subtidal station $\mathrm{C}$, are of the same order of magnitude as those obtained by other authors (Table 4).

At station $C$ three elements, lower $I_{c}$ than observed irradiance, the fact the algae presented a normal adaptation pattern to irradiance, and the usual $\mathrm{P}_{\max }$ value, all reinforce the hypothesis of in situ growth of Ulva spp..

Secondly, during the study period, water DIN ranged between 4.7 and $657 \mu \mathrm{mol}^{-1}$ at stations $\mathrm{A}$ and $\mathrm{B}$, i.e. 0.07 and $9.2 \mathrm{mg} \mathrm{N} \mathrm{I}^{-1}$, whereas other studies showed that a concentration of $0.1 \mathrm{mg} \mathrm{I}^{-1}$ was the lowest nitrogen limit for proliferation of green algae to be possible (Morand and Briand, 1996). This limit was only reached in July. The very high DIN value recorded on June 21 at station A (656 $\left.\mu \mathrm{mol} \mathrm{I}^{-1}\right)$ corresponded to the totally fresh water composition of the sample with a very high nitrate load. Otherwise, the decrease in nitrate (+ nitrite) over time was likely due, at least in stations A and B, to the drop in input from streams (reduction in flow rates and concentrations as reported in a previous study (Merceron et al. 1999)). At station C, five water samples out of seven displayed DIN values under $7 \mu \mathrm{mol} \mathrm{I}^{-1}$ (i.e. $0.1 \mathrm{mg} \mathrm{l}^{-1}$ ), and, five times, the DIN concentration in the water was much lower than at stations $A$ and $B$ (an average of $4.9 \mu \mathrm{mol} \mathrm{I}^{-1}$ at station $C$ compared to 27.4 at station $B$ ).

Despite the differences in the DIN concentrations in the water surrounding the algae, the nitrogen content of Ulva spp. tissues in the three stations was very similar, i.e. always above 1\% DW (Fig. 2) and thus above the threshold value of nitrogen which sharply limits growth, as determined by Dion et al. (1996). It was frequently close to or above the critical value, defined as the concentration at which the maximum growth rate of the alga is reached. This critical value has been estimated to be $2 \% \mathrm{DW}$ for Ulva rigida for instance (Lavery and McComb, 1991).

Several hypotheses can be put forward to explain why the nitrogen contents of Ulva spp. at station C were sufficient to ensure their growth, even when the DIN content of the surrounding water was less than $2 \mu \mathrm{mol} \mathrm{l}^{-1}$ :

i) Hypothesis 1: The low DIN concentration can support prolonged growth at reduced rates because the growth rate is limited by the PAR intensity, or low DIP concentration. Thus, the lower DIN concentration results in a reduced uptake rate, but this rate is matched by the reduced $\mathrm{N}$-demand of the algae.

ii) Hypothesis 2: Ulva colonizes greater depths mainly due to substantial advective transport which results in net import of biomass. 
iii) Hypothesis 3: At greater depths Ulva growth depends mainly on nutrients delivered from the sediment by hydrodynamic pumping due to the ripple marks, a phenomenon that could locally increase $\mathrm{NH}_{4}{ }^{+}$release from sediments (Huettel et al., 1998).

Ulva spp. adaptability to lower irradiance levels (Table 3 ) seems to contradict hypothesis 1 , as far as a possible limitation by PAR is concerned. For $\mathrm{P}$, the hypothesis remains to be tested, although a limitation of $\mathrm{N}$ coupled with a limitation of $\mathrm{P}$ would be expected to drastically reduce growth.

Indeed, despite the mobility of the intertidal fraction under specific weather conditions we previously observed (Merceron and Morand, 2004), an advection model showed that the residual current alone would enable Ulva spp. to travel only $500 \mathrm{~m}$ in more than 5 days. As stations B and C are at least one $\mathrm{km}$ apart and the seven samplings at these two stations were systematically made at only at an interval of two days, no mechanism can be proposed to support hypothesis 2 .

Finally, the thalli in fact most often lie gently on the bottom. There, there are nutrient exchanges between the sediment pore water and the water lying immediately above it. DIN being released from the sediment could be captured by Ulva spp. and thus be much less perceptible or even imperceptible at $0.3 \mathrm{~m}$ above the bottom. Thybo-Christensen et al. (1993) and Trimmer et al. (2000) showed that sediment is probably a significant source of regenerated nutrients which can support the growth of established algal blooms. In addition, Sundbäck et al. (2003) indicated that nitrogen fluxes of benthic origin could provide from 55 to $100 \%$ of the estimated demand for an algal bloom at its outset. McGlathery et al. (1997) and Krause-Jensen et al. (1999) noted the absence of increase in nitrogen compounds in the water column above a mat of Chaetomorpha linum (O.F. Müller) Kützing whose base was abundantly supplied with $\mathrm{NH}_{4}{ }^{+}$by the sediment. In the middle of the Bay of Douarnenez, a clearly subtidal area, Birrien (1987) observed significant $\mathrm{NH}_{4}^{+}$releases from the bottom in June and September. In the Le Frêt cove (10 m deep), in the Bay of Brest, a site similar to the Bay of Douarnenez, Douchement (1987) calculated the monthly diffusive flux of $\mathrm{NH}_{4}{ }^{+}$from the sediment into the overlying water. The annual mean flux was $33.0 \pm 11.6 \mu \mathrm{mol} \mathrm{m}^{-2} \mathrm{~h}^{-1}$ with a minimum in spring and a maximum from July to October. Auby et al. (1994) also measured considerable Summer releases of ammonium from subtidal sediments in the Arcachon Basin, another macrophytic bloom site on the Atlantic coast of France. Therefore, hypothesis 3 is the most likely. Nevertheless, subtidal growth of Ulva spp. should be slower than that in intertidal areas, since their maximum oxygen production is from 1 to 1.6 times lower. This could be explained by temperature (Table 1) and irradiance (Fig. 6). At station $C$, algae growth was partly limited by ambient irradiance mostly lower than $I_{k}$, in contrast to station B. Lower availability of nitrogen may also be involved. In this respect, subtidal sediments could have become loaded with nitrogen over successive years of green tides, due to the degradation of thalli, whether from the intertidal or subtidal stocks, as well as the migration of foreshore sediments to subtidal depths.

The next useful step would be to check if one Ulva spp. stock - intertidal or subtidal - appears sooner than the other in any given year that could initiate the growing season in both zones. This could have significant consequences for corrective measures for green tides.

\section{Acknowledgements}

We thank Jacqueline Le Grand for providing help during field sampling, and Roger Kerouel and Philippe Cann for chemical analyses. We are grateful to the referees and to the editor for their very useful comments. 


\section{REFERENCES}

Aminot A. Quality assurance of pre-determination steps for dissolved nutrients in marine samples. In: Quevauviller P, editor. Quality assurance in environmental monitoring - Sampling and sample pretreatment. $\mathrm{VCH}$, Weinheim, Germany; 1995. p. 91-112.

Anonymous. Atlas hydrologique de Bretagne. Agence de l'Eau Loire-Bretagne, Orléans (France); 1995.

Auby I, Manaud F, Maurer D, Trut G. Étude de la prolifération des algues vertes dans le bassin d'Arcachon. Rapport IFREMER - CEMAGREF - SSA - SABARC; 1994. 163 pp.

Birrien J-L. Cycles de variations des éléments nutritifs et du phytoplancton en baie de Douarnenez et dans les secteurs adjacents : importance du front côtier de l'Iroise. Thèse de doctorat d'état, Université de Bretagne Occidentale, Brest (France); 1987. 160 pp.

Bourgoin A, Guillou M, Glémarec M. Environmental instability and demographic variability in Acrocnida brachiata (Echinodermata: Ophiuroidea) in Douarnenez Bay (Brittany: France). PSZNI: Mar Ecol 1991;12:89-104.

Brush M J, Nixon S W. Biomass layering and metabolism in mats of the macroalga Ulva lactuca $\mathrm{L}$. Estuaries 2003;26(4A):916-26.

CEVA. Consolidation du diagnostic antérieur concernant la résistance potentielle du site aux mesures préventives et suivi d'indicateurs d'évolution en mer pour l'année 2000. Rapport à la Communauté de Communes de Lannion, Perros-Guirec, Plestin-les-Grèves, Côte-de-Granit (France); 2000. 13 pp.

Chaquin P. Diagnostic du bassin versant du Lesnevard/Saint-Jean dans le cadre du pré-programme de lutte contre les algues vertes. Rapport aux Communautés de communes du Pays Fouesnantais et de Concarneau-Cornouaille (France); 2000. 68 pp.

De Casabianca M-L. France-The Mediterranean lagoons. In: Schramm W, Nienhuis PH, editors. Marine benthic vegetation. Recent changes and the effects of eutrophication. Springer-Verlag, Berlin; 1996. p. 307-29.

Dion P, Le Bozec S. The French Atlantic coasts. In: Schramm W, Nienhuis PH, editors. Marine benthic vegetation. Recent changes and the effects of eutrophication. Springer-Verlag, Berlin, Heidelberg; 1996. p. 251-64.

Dion P, Le Bozec S, Golven P. Factors controlling the green tides in the bay of Lannion (France). In: Rijstenbil JW, Kamermans P, Nienhuis PH, editors. Synthesis report of the Second EUMAC Workshop, held in Sète (France); 1996. p. 121-37.

Dion P, Reviers B de, Coat G. Ulva armoricana sp.nov. (Ulvales, Chlorophyta) from the coasts of Brittany (France). I. Morphological identification. Eur J Phycol 1998;33:73-80.

Douchement C. Chimie de deux milieux marins anoxiques. Eaux hydrothermales et eaux interstitielles des sédiments. Méthodologie des prélèvements et des analyses des composés de l'azote, du phosphore, et du silicium. Dynamique de leur circulation en sédiments côtiers. Thèse de doctorat, Université de Bretagne Occidentale, Brest (France); 1987. 215 pp.

Fong P, Zedler JB, Donohoe RM. Nitrogen vs. phosphorus limitation of algal biomass in shallow coastal lagoons. Limnol Oceanogr 1993;38:906-23.

Fortes MD, Lüning K. Growth rates of North Sea macroalgae in relation to temperature, irradiance and photoperiod. Helgol Meeresunters 1980;34:15-29.

Geertz-Hansen O, Sand-Jensen K. Growth rates and photon yield of growth in natural populations of a marine macroalga Ulva lactuca. Mar Ecol Prog Ser 1992;81:179-83. 
Han T, Han Y-S, Kain JM, Häder D-P. Thallus differentiation of photosynthesis, growth, reproduction, and UV-B sensitivity in the green alga Ulva pertusa (Chlorophyceae). J Phycol 2003;39:712-21.

Henley WJ, Levavasseur G, Franklin LA, Osmond CB, Ramus J. Photoacclimation and photoinhibition in Ulva rotundata as influenced by nitrogen availability. Planta 1991;184:235-43.

Henley W J, Lindley S T, Levavasseur G, Osmond CB, Ramus J. Photosynthetic response of Ulva rotundata to light and temperature during emersion on an intertidal sand flat. Oecologia 1992;89:51623.

Huettel M, Ziebis W, Forster S, Luther GW III. Advective transport affecting metal and nutrient distributions and interfacial fluxes in permeable sediments. Geochim Cosmochim Acta 1998;62:613631.

Jeffrey SW, Humphrey GF. New spectrophotometric equations for determining chlorophylls $\underline{a}, \underline{b}, \underline{c}_{1}$ and $\underline{\underline{c}}_{2}$ in higher plants, algae and natural phytoplankton. Biochem Physiol Pflanz 1975;167:191-4.

Kérouel $\mathrm{R}$, Aminot A. Fluorometric determination of ammonia in sea and estuarine waters by direct segmented flow analysis. Mar Chem 1997;57:265-75.

Krause-Jensen D, Christensen P B, Rysgaard S. Oxygen and nutrient dynamics within mats of the filamentous macroalga Chaetomorpha linum. Estuaries 1999;22(1):31-8.

Lavery P S, Mac Comb A J. The nutritional eco-physiology of Chaetomorpha linum and Ulva rigida in Peel Inlet, Western Australia. Bot Mar 1991;34:251-60.

Levavasseur G. Teneur en pigments et activité photosynthétique comparées de diverses algues macrophytes de la zone intertidale de Roscoff. Cryptogam Algol 1987;8(4):253-71.

Levavasseur G, Giraud G. Modification de la photosynthèse nette d'une ulve de Roscoff en fonction de la durée d'éclairement. Physiol vég 1982;20(2):143-54.

Littler MM, Littler DS. The evolution of thallus form and survival strategies in benthic marine macroalgae: field and laboratory tests of a functional form model. Am Nat 1980;116:25-44.

McGlathery KJ, Krause-Jensen D, Rysgaard S, Christensen PB. Patterns of ammonium uptake within dense mats of the filamentous macroalga Chaetomorpha linum. Aquat Bot 1997;59:99-115.

Menéndez $\mathrm{M}$, Martinez $\mathrm{M}$, Comin FA. A comparative study of the effect of $\mathrm{pH}$ and inorganic carbon resources on the photosynthesis of three floating macroalgae species of a Mediterranean coastal lagoon. J Exp Mar Biol Ecol 2001;256:123-36.

Ménesguen A, Piriou J-Y. Nitrogen loadings and macroalgal (Ulva sp.) mass accumulation in Brittany (France). Ophelia 1995;42:227-37.

Mercado J M, Avilés A, Benites E, Carrasco M, Palomo L, Clavero V, Niell FX. Photosynthetic production on Ulva rotundata Bliding estimated by oxygen and inorganic carbon exchange measurements in the field. Bot Mar 2003;46:342-9.

Merceron M. Inventaire des ulves en Bretagne - Année 1997. Rapport de synthèse. Rapport IFREMER, DEL/98.02/Brest (France); 1998.18 pp.

Merceron M. Inventaire des ulves en Bretagne - Année 1998. Rapport de synthèse. Rapport IFREMER, DEL/99.15/Brest (France); 1999. 26 pp.

Merceron M, Morand P. Existence of a subtidal stock of drifting Ulva in relation to intertidal algal mat developments. J Sea Res 2004;52:269-80.

Merceron M, Coïc D, Talec P. Biomasses d'ulves et flux de nutriments en baie de Douarnenez. In : 
Merceron $M$, editor. Pollutions diffuses : du bassin versant au littoral. Actes de colloques 24, IFREMER, Brest (France); 1999. pp. 49-60.

Morand $\mathrm{P}$, Briand X. Excessive growth of macroalgae: a symptom of environmental disturbance. Bot Mar 1996;39:491-516.

Morand P, Merceron M. Coastal eutrophication and excessive growth of macroalgae. In: Pandalai SG, editor. Recent Research Developments in Environmental Biology. Vol. 1(2). Research Signpost, Trivandrum, Kerala, India; 2004. p. 395-449.

Obaton D. Caractéristiques hydrodynamiques du littoral Sud Bretagne. Rapport IFREMER, DEL/9605/Brest (France); 1996. 23 pp.

Pedersen MF. Nitrogen limitation of photosynthesis and growth: comparison across aquatic plant communities in a Danish estuary (Roskilde Fjord). Ophelia 1995;41: 261-72.

Pérez-Llorens JL, Vergara JJ, Pino RR, Hernandez I, Peralta G, Niell FX. The effect of photoacclimation on the photosynthetic physiology of Ulva curvata and Ulva rotundata (Ulvales, Chlorophyta). Eur J Phycol 1996;31:349-59.

Pihl L, Magnusson G, Isaksson I, Wallentinus I. Distribution and growth dynamics of ephemeral macroalgae in shallow bays on the Swedish west coast. J Sea Res 1996;35:169-80.

Plus M, Auby I, Verlaque M, Levavasseur G. Seasonal variations in photosynthetic irradiance response curves of macrophytes from a Mediterranean coastal lagoon. Aquat Bot 2005;81:157-73.

Ramus J, Venable M. Temporal ammonium patchiness and growth rate in Codium and Ulva (Ulvophyceae). J Phycol 1987;23:518-23.

Riccardi N, Solidoro C. The influence of environmental variables on Ulva rigida C. Ag. growth and production. Bot Mar 1996;39:27-32.

Rivers J S, Peckol P. Summer decline of Ulva lactuca (Chlorophyta) in a eutrophic embayment: interactive effects of temperature and nitrogen availability? J Phycol 1995;31:223-8.

Rosenberg G, Ramus J. Uptake of inorganic nitrogen and seaweed surface area: volume ratios. Aquat Bot 1984;19:65-72.

Sand-Jensen K. Photosynthetic responses of Ulva lactuca at very low light. Mar Ecol Prog Ser 1988b;50:195-201.

Schramm W, Nienhuis PH. Introduction. In: Schramm W, Nienhuis PH. editors. Marine benthic vegetation. Recent changes and the effects of eutrophication. Springer-Verlag, Berlin, Heidelberg; 1996. p. 1-4.

SEAMER-CEVA. Pré-programme de lutte contre les algues vertes en baie de Douarnenez. Lot $n^{\circ} 4$ Modélisation mathématique. Rapport à la Communauté de communes du Porzay-Ménez-Hom (France); 2001. 57 pp.

Sfriso A, Pavoni B, Marcomini A, Orio AA. Annual variations of nutrients in the lagoon of Venice. Mar Pollut Bull 1988;19:54-60.

Sundbäck K, Miles A, Hulth S, Pihl L, Engström P, Selander E, Svenson A. Importance of benthic nutrient regeneration during initiation of macroalgal blooms in shallow bays. Mar Ecol Prog Ser 2003;246:115-26.

Taylor R, Fletcher RL, Raven JA. Preliminary studies on the growth of selected "green tide" algae in laboratory culture: effects of irradiance, temperature, salinity and nutrients on growth rate. Bot Mar 2001;44:327-36. 
Thybo-Christesen M, Rasmussen MB, Blackburn TH. Nutrient fluxes and growth of Cladophora sericea in a shallow Danish bay. Mar Ecol Prog Ser 1993;100:273-81.

Tréguer $\mathrm{P}$, Le Corre P. Manuel d'analyse des sels nutritifs dans l'eau de mer. Utilisation de I'AAll Technicon. UBO éditions, Brest (France); 1974.

Trimmer M, Nedwell DB, Sivyer DB, Malcolm SJ. Seasonal organic mineralization and denitrification in intertidal sediments and their relationship to the abundance of Enteromorpha sp. and Ulva sp. Mar Ecol Prog Ser 2000;203:67-80.

Vergara J J, Sebastian M, Pérez-Llorens JL, Hernandez I. Photoacclimation of Ulva rigida and U. rotundata (Chlorophyta) arranged in canopies. Mar Ecol Prog Ser 1998;165:283-92.

Vermaat JE, Sand-Jensen K. Survival, metabolism and growth of Ulva lactuca under winter conditions: a laboratory study of bottlenecks in the life cycle. Mar Biol 1987;95:55-61.

Webb WL, Newton M, Starr D. Carbon dioxide exchange of Alnus rubra: a mathematical model. Oecologia 1974;17:281-91. 

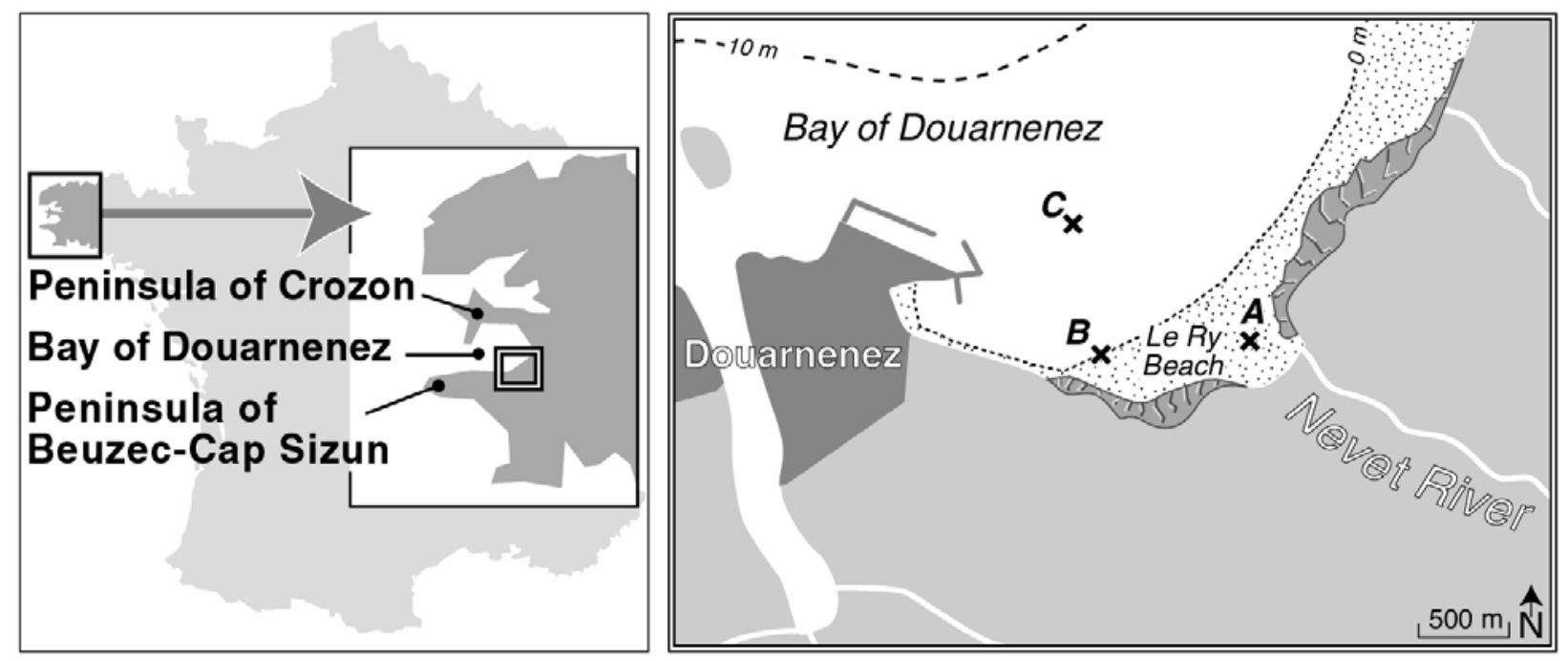

Fig. 1. Location of sampling sites in the Bay of Douarnenez. GPS position at station C: $04^{\circ} 18^{\prime} 739 \mathrm{~W}$; $48^{\circ} 06^{\prime} 069 \mathrm{~N}$. 

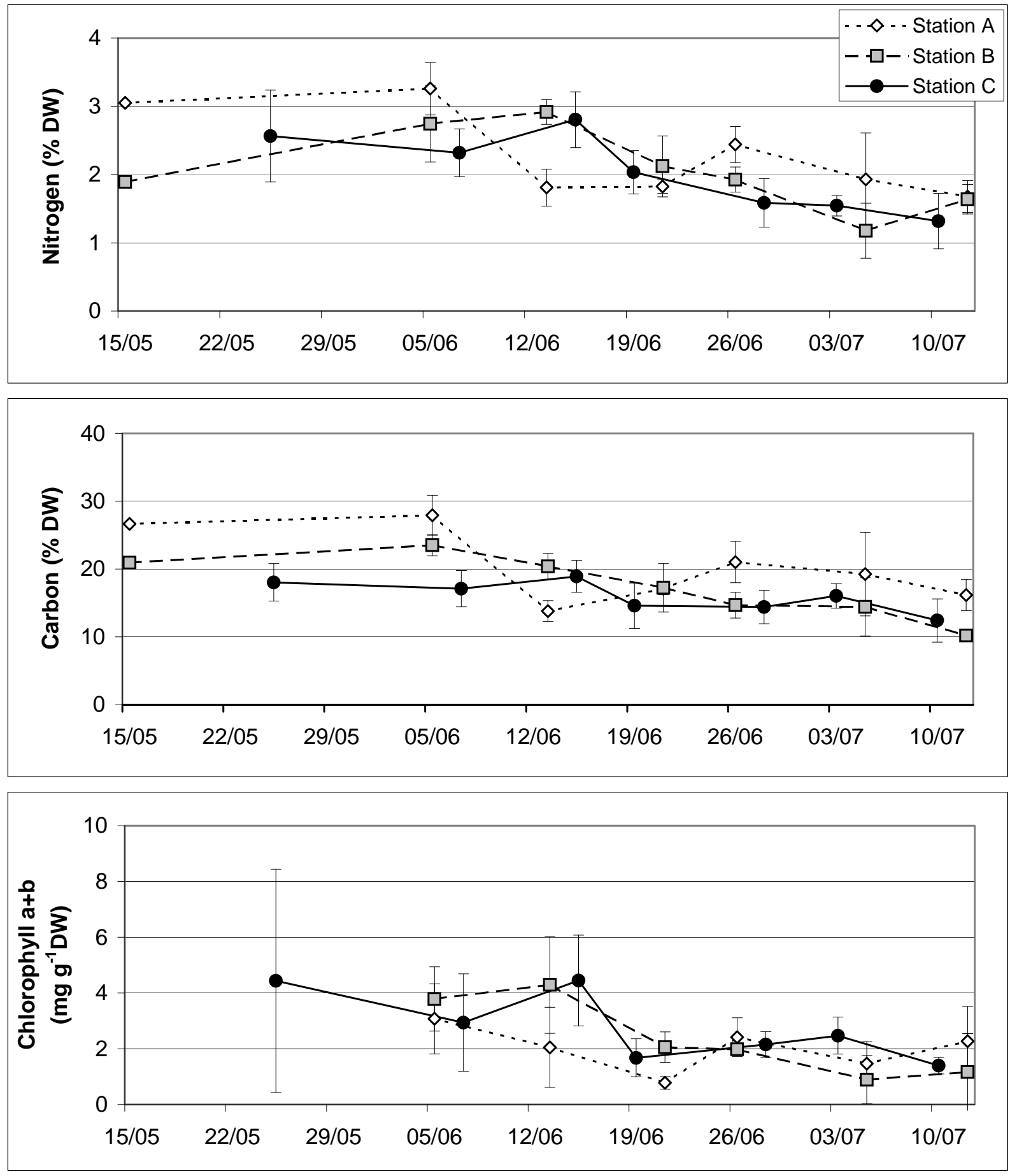

Fig. 2. Nitrogen, carbon and chlorophylls $\mathrm{a}+\mathrm{b}$ content of Ulva during the period of maximum growth; means and standard deviations from five or six measurements except on May 15 (one measurement); station A: foreshore, station B: surf zone, station C: subtidal zone. 

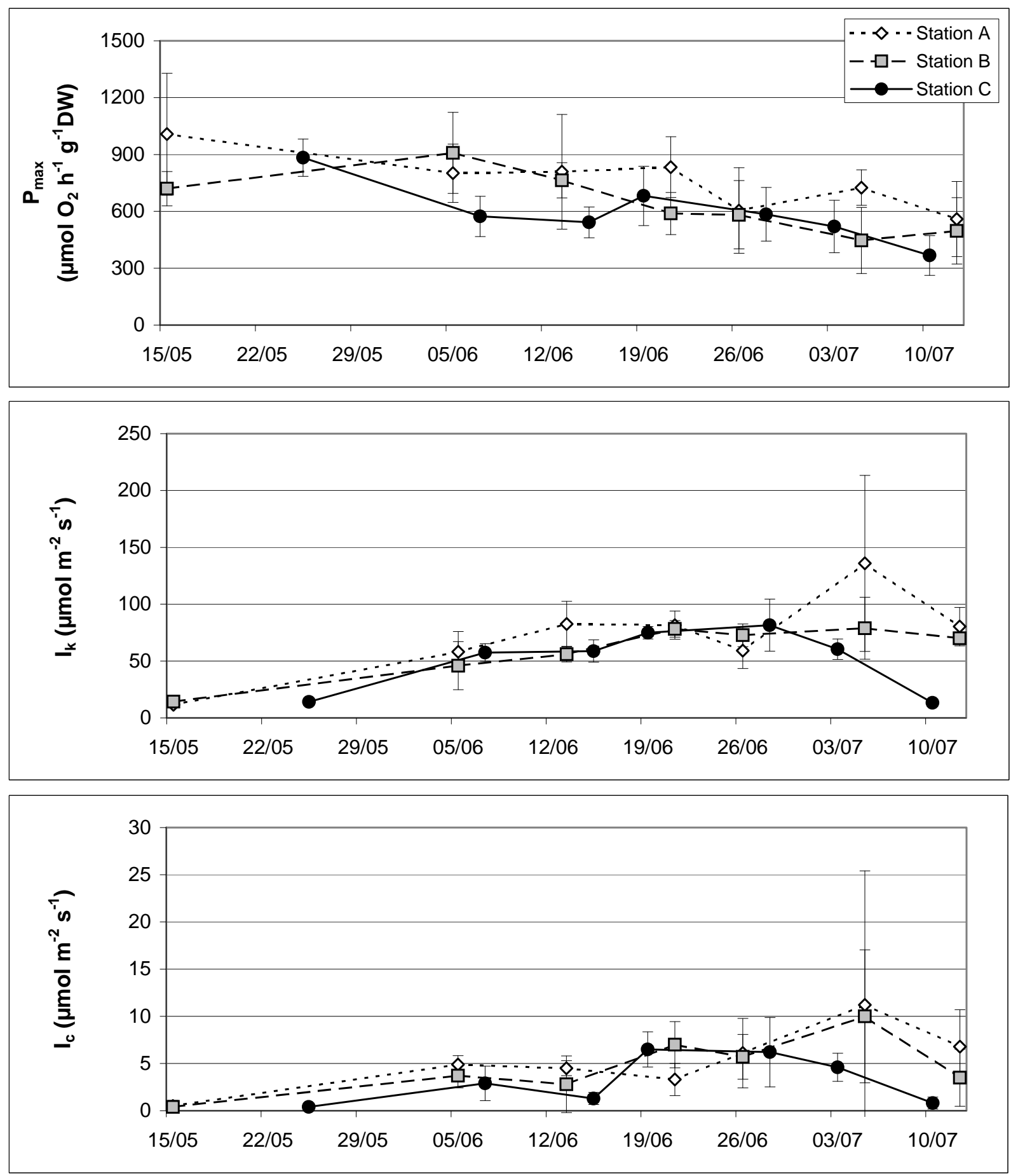

Fig. 3. Photosynthetic parameters of Ulva during the period of maximum growth: maximum photosynthesis production $\left(P_{\max }\right)$, saturating irradiance $\left(I_{k}\right)$, compensating irradiance $\left(I_{c}\right)$; means and standard deviations from five or six measurements; station A: foreshore, station B: surf zone, station C: subtidal zone. 


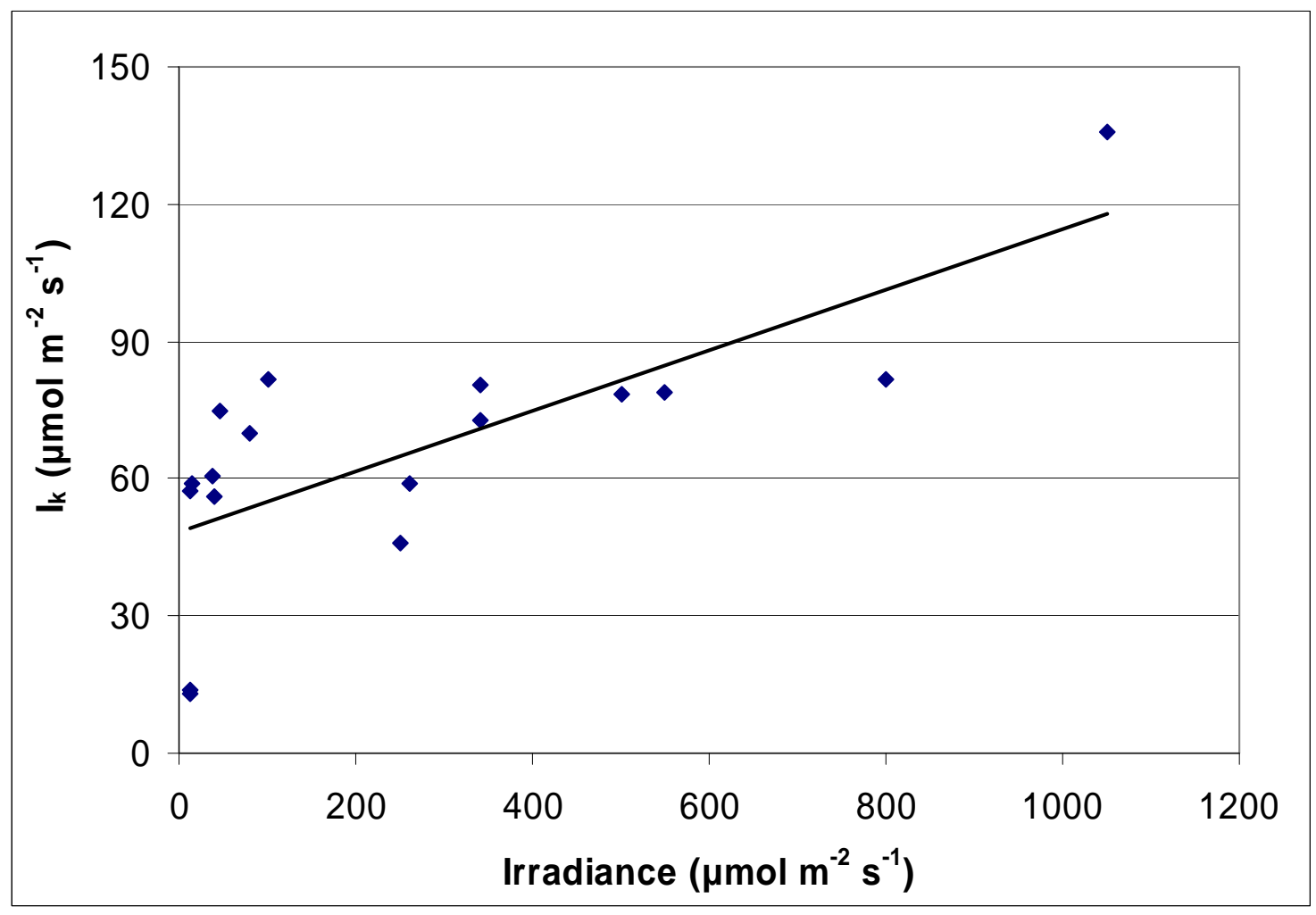

Fig. 4. Correlation between irradiance (I) and saturating irradiance $\left(\mathrm{I}_{\mathrm{k}}\right)$ from data of stations $A, B$ and $C$ taken together. $I_{k}=0.07 I+48.5 ; n=17 ; r=0.738 ; p>0.99$.

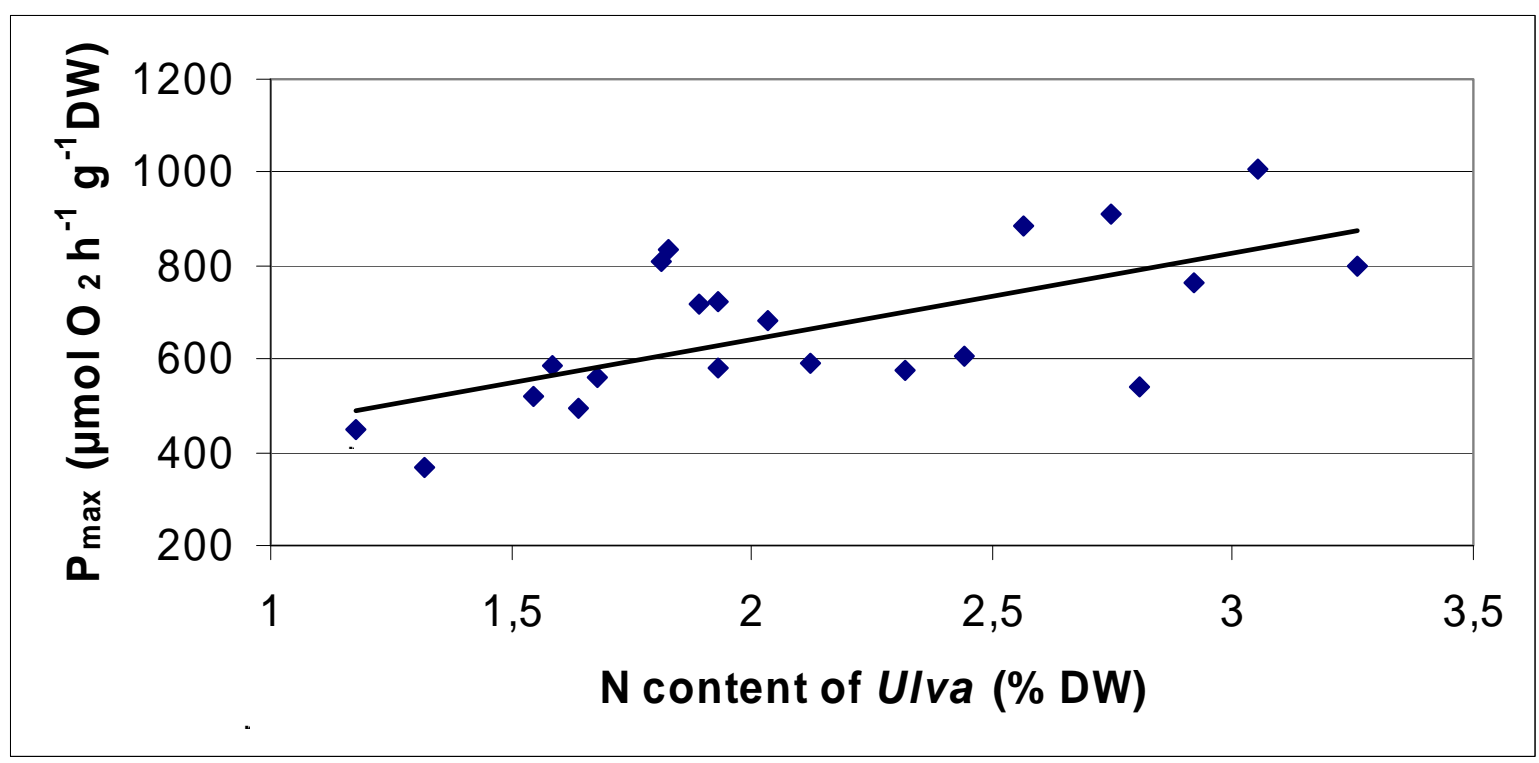

Fig. 5. Correlation between $\mathrm{N}$ content and $\mathrm{P}_{\max }$ of Ulva spp. Data from stations $\mathrm{A}, \mathrm{B}$ and $\mathrm{C}$ taken together. $\mathrm{P}_{\max }=185 \mathrm{~N}$ content $+273 ; \mathrm{n}=21 ; \mathrm{r}=0.654 ; \mathrm{p}>0.99$. 

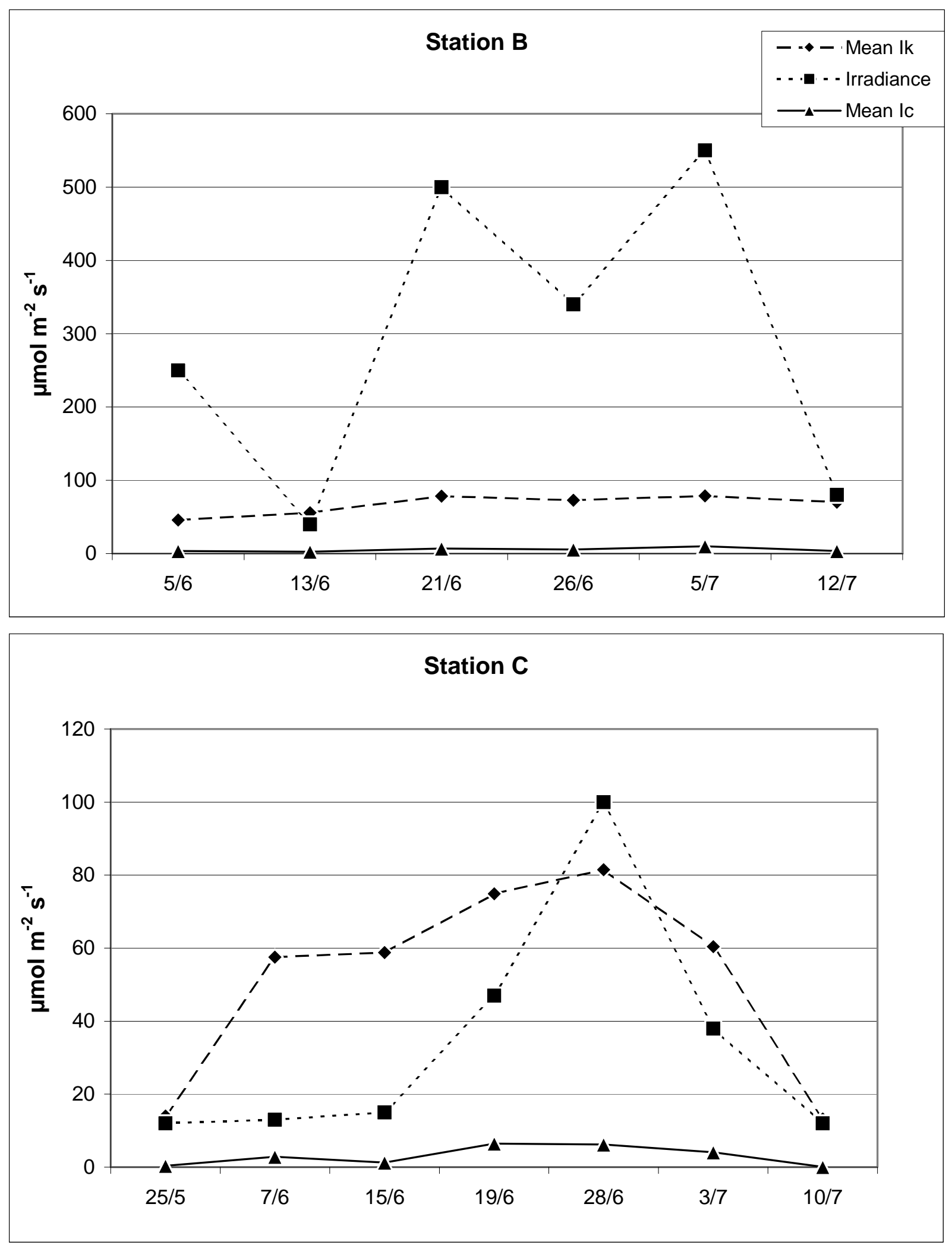

Fig. 6. Comparison between observed ambient irradiance and Ulva spp. $I_{k}$ and $I_{c}$ at stations $B$ (surf zone) and C (subtidal zone). 
Table 1

Physical and chemical characteristics of seawater in the nearby environment of sampled Ulva

\begin{tabular}{|c|c|c|c|c|c|c|c|c|}
\hline Station $^{a}$ & Date & $\begin{array}{l}\text { Depth } \\
\text { (m) }\end{array}$ & $\begin{array}{l}\text { Temperature } \\
\qquad\left({ }^{\circ} \mathrm{C}\right)\end{array}$ & Salinity & $\begin{array}{l}\text { Irradiance } \\
\left(\mu \mathrm{mol}^{\mathrm{b}} \mathrm{m}^{-2}\right. \\
\left.\mathrm{s}^{-1}\right)\end{array}$ & $\begin{array}{l}\mathrm{N}-\mathrm{NO}_{3}^{-}+\mathrm{N}- \\
\mathrm{NO}_{2}^{-} \\
(\mu \mathrm{mol} \mathrm{I} \\
-1\end{array}$ & 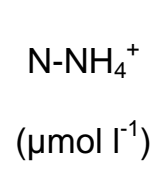 & $\begin{array}{c}\mathrm{DIN}^{\mathrm{C}} \\
\left(\mu \mathrm{mol} \mathrm{I}{ }^{-1}\right)\end{array}$ \\
\hline$A$ & 15/5/00 & - & 24,6 & 37 & n.r. ${ }^{d}$ & 177 & 4,24 & 181 \\
\hline " & 5/6/00 & - & 17,0 & 28 & n.r. & 68,7 & 2,04 & 70,7 \\
\hline$"$ & $13 / 6 / 00$ & - & 20,0 & 35 & n.r. & 40,5 & 3,09 & 43,6 \\
\hline$"$ & $21 / 6 / 00$ & - & 24,5 & 0 & 800 & 654 & 2,80 & 657 \\
\hline$"$ & 26/6/00 & - & 12,6 & 37 & 261 & 3,25 & 6,60 & 9,85 \\
\hline$"$ & $5 / 7 / 00$ & - & 24,1 & 40 & 1051 & 0,60 & 5,69 & 6,28 \\
\hline " & $12 / 7 / 00$ & - & 16,5 & 42 & 342 & 0,73 & 3,93 & 4,66 \\
\hline B & $15 / 5 / 00$ & n.r. & 16,5 & 32 & n.r. & 47,0 & 5,42 & 52,4 \\
\hline " & 5/6/00 & 0,7 & 15,0 & 32 & 250 & 85,6 & 0,33 & 85,9 \\
\hline$"$ & 13/6/00 & 0,5 & 16,0 & 32 & 40 & 12,5 & 2,17 & 14,7 \\
\hline$"$ & $21 / 6 / 00$ & 0,7 & 17,1 & 34 & 500 & 4,15 & 2,87 & 7,01 \\
\hline$"$ & 26/6/00 & 0,6 & 17,8 & 33 & 340 & 19,2 & 0,99 & 20,1 \\
\hline$"$ & $5 / 7 / 00$ & 0,7 & 18,8 & 34 & 550 & 0,65 & 5,54 & 6,19 \\
\hline$"$ & $12 / 7 / 00$ & 0,6 & 16,2 & 34 & 80 & 2,83 & 2,71 & 5,54 \\
\hline C & $25 / 5 / 00$ & 10 & 14,0 & 35 & 12 & 5,93 & 1,75 & 7,68 \\
\hline " & 7/6/00 & 11 & 14,2 & 34 & 13 & 4,90 & 1,75 & 6,65 \\
\hline " & 15/6/00 & 8 & 14,6 & 34 & 15 & 2,66 & 0,91 & 3,56 \\
\hline$"$ & 19/6/00 & 9 & 13,0 & 34 & 47 & 5,19 & 3,08 & 8,27 \\
\hline$"$ & $28 / 6 / 00$ & 8 & 14,9 & 35 & 100 & 0,52 & 1,12 & 1,65 \\
\hline " & $3 / 7 / 00$ & 9 & 14,7 & 35 & 38 & 0,20 & 1,64 & 1,85 \\
\hline " & 10/7/00 & 9 & 16,5 & 34 & 12 & 1,18 & 3,28 & 4,46 \\
\hline \multicolumn{9}{|c|}{$\begin{array}{l}\text { a Station A: foreshore, B: surf zone, C: subtidal zone } \\
\text { b for station A: downwelling irradiance; for stations B and C: scalar } \\
\text { irradiance }\end{array}$} \\
\hline \multicolumn{9}{|c|}{$\begin{array}{l}{ }^{\mathrm{c}} \mathrm{DIN}: \mathrm{N}-\mathrm{NO}_{3}^{-}+\mathrm{N}-\mathrm{NO}_{2}^{-}+\mathrm{N}-\mathrm{NH}_{4}^{+} \\
{ }^{\mathrm{d}} \text { n.r.: not recorded. }\end{array}$} \\
\hline
\end{tabular}


Table 2

Correlation probability between the three Ulva parameters nitrogen, carbon and photosynthesis maximun productio $\left(\mathrm{P}_{\max }\right)$ tested by ANOVA by station

\begin{tabular}{|c|c|c|c|c|}
\hline Probability of correlation between parameters ${ }^{\mathrm{a}, \mathrm{b}}$ & & Nitrogen & Carbon & $\mathrm{P}_{\max }$ \\
\hline \multirow[t]{3}{*}{ at station $A^{c}$} & Nitrogen & & $>0.99(30)$ & n.s. ${ }^{d}(29)$ \\
\hline & Carbon & & & n.s. (29) \\
\hline & $P_{\max }$ & & & \\
\hline \multirow[t]{3}{*}{ at station $\mathrm{B}^{\mathrm{C}}$} & Nitrogen & & $>0.99(30)$ & $>0.99$ (28) \\
\hline & Carbon & & & $>0.99(28)$ \\
\hline & $\mathrm{P}_{\max }$ & & & \\
\hline \multirow[t]{3}{*}{ at station $\mathrm{C}^{\mathrm{c}}$} & Nitrogen & & $>0.99(34)$ & $>0.99$ (33) \\
\hline & Carbon & & & n.s. (33) \\
\hline & $\mathrm{P}_{\max }$ & & & \\
\hline
\end{tabular}

${ }^{\mathrm{a}}$ Pair numbers between parentheses.

${ }^{b}$ Correlation tested thallus by thallus, generally 5 thalli at each station and date; aberrant values discarded from tests.

${ }^{\mathrm{c}}$ Stations A: foreshore, B: surf zone, C: subtidal zone.

${ }^{d}$ n.s.: not significant. 
Table 3

Growth of different Ulva species under low irradiances

\begin{tabular}{|c|c|c|c|c|}
\hline Species & $\begin{array}{l}\text { Irradiance } \\
\left(\begin{array}{c}\mu \mathrm{mol} \mathrm{m} \mathrm{m}^{-2} \mathrm{~s}^{-} \\
{ }^{\prime}\end{array}\right.\end{array}$ & $\begin{array}{l}\text { Photoperiod } \\
\text { (light:dark) }\end{array}$ & $\begin{array}{l}\text { Growth } \\
\left(\% j^{-1}\right)\end{array}$ & References \\
\hline U. lactuca L. & $\begin{array}{l}30 \\
0,6 \\
2,5\end{array}$ & $\begin{array}{l}16: 08 \\
24: 00 \\
24: 00\end{array}$ & $\begin{array}{l}\text { 6 } \\
\text { threshold } \\
\text { threshold }\end{array}$ & $\begin{array}{l}\text { Fortes and Lüning (1980) } \\
\text { Vermaat and Sand-Jensen } \\
\text { (1987) } \\
\text { Sand-Jensen (1988) }\end{array}$ \\
\hline $\begin{array}{l}U . \text { curvata (Kütsing) } \\
\text { U. rotundata Kützing }\end{array}$ & 60 & $12: 12$ & 7 & Pérez-Llorens et al. (1996) \\
\hline U. rigida C. Agardh & 1,9 & (unknown) & threshold & Riccardi and Solidoro (1996) \\
\hline U. curvata (Kütsing) & 10 & $16: 08$ & 9,5 & Taylor et al. (2001) \\
\hline
\end{tabular}


Table 4

Comparison of maximum photosynthesis production $\left(\mathrm{P}_{\max }\right)$ of different Ulva species from several authors

\begin{tabular}{ccl}
\hline Ulva species & $\mathrm{P}_{\max }$ & \multicolumn{1}{c}{ References } \\
& $\left(\mu \mathrm{mol} \mathrm{O} \mathrm{h}^{-1} \mathrm{~g}^{-1} \mathrm{DW}\right)^{\mathrm{a}}$ & \\
\hline U. rotundata & 997 & Henley et al. (1991) \\
& $<=2120^{\mathrm{b}}$ & Henley et al. (1992) \\
& 623 & Pérez-Llorens et al. (1996) \\
& 1084 & Mercado et al. (2003) \\
U. rigida & 523 & Vergara et al. (1998) \\
U. pertusa & 997 & " \\
& 872 & Pérez-Llorens et al. (1996) \\
U. lactuca & $195-1344^{\mathrm{c}}$ & Han et al. (2003) \\
U. sp. & $450-1147^{\mathrm{d}}$ & Rivers and Peckol (1995) \\
U. sp. & $500-770$ & Brush and Nixon (2003) \\
U. sp. & 403 & Menéndez et al. (2001) \\
U. spp. & $758-2342^{\mathrm{e}}$ & Levavasseur and Giraud (1982) \\
U. spp. & $844-1219^{\mathrm{f}}$ & Levavasseur (1987) \\
\hline
\end{tabular}

a original data expressed in relation to $\mathrm{m}^{2}$ by some authors were converted using the ratio of $1 \mathrm{~m}^{2}$ of thallus corresponding to 14.444 gDW.

${ }^{b}$ thalli stranded on foreshore subjected to a natural irradiance of $2300 \mu \mathrm{mol}$ photons $\mathrm{m}^{-2} \mathrm{~s}^{-1}$.

${ }^{\mathrm{c}} \mathrm{P}_{\max }$ measured respectively at base and apex of thallus.

${ }^{\mathrm{d}} \mathrm{P}_{\max }$ respectively measured in summer and spring.

${ }^{\mathrm{e}} \mathrm{P}_{\max }$ corresponding to measurements performed respectively in April under high irradiance and in July under low irradiance.

${ }^{\mathrm{f}} \mathrm{P}_{\max }$ measured respectively in deep (subtidal) and intertidal Ulva.

${ }^{9} \mathrm{P}_{\max }$ measured respectively in May and July.

${ }^{h}$ the three values correspond respectively to the stations A (foreshore), B (surf zone) and C (subtidal zone) in the present study. 